\section{Deforestation: call for justice, not militarization}

SIR - As a recent policy adviser to the United Nations in a programme intended to address environmental threats in the Amazon, I would caution readers of your Special Report 'Brazil goes to war against logging' (Nature 452, 134-135; 2008). Although this analysis of Brazil's "militarystyle crackdown on deforestation" is valuable, it perpetuates some perilous assumptions.

You aptly note that mining on the fringes is among the problems, but I would question some of the solutions you suggest. Urging international donors to help national governments such as Brazil to fund 'traditional' policies for enforcement neglects the reality that local governance agents, not national enforcers, can be more appropriate custodians; foreign donors frequently make this mistake. Also, there needs to be greater global awareness of the unwanted consequences of the so-called traditional policies of eco-militarization, which have wrought pervasive problems not only in the Amazon but worldwide.

Police interference in indigenous people's lives can have devastating effects, often leading to more environmental harm rather than less. My own experience with peasants who mine illegally in conservation areas suggests that resentment of the government drives illegality and marginalization. For example, indigenous groups in the Amazon captured more than 600 hostages in the past two years, protesting against injustices with regards to mining rights. One tribe took a UN worker and four others hostage a few months ago, angry that the government and international agencies ignored their resource claims; the government sent in police troops instead. That tribe was seeking the rights to mine its land - but only a multinational corporation was granted those rights. Brazil has millions of peasant ('artisanal') miners, but licences only very rarely go to poorer communities.

Some 337 large-scale commercial mining permits violate Brazilian law, falling within 28 federal conservation areas; another 5,283 pending applications also impinge on federal conservation areas.

Environmental violations are pervasive in both legal and illegal scenarios - and the concept of legality itself is blurred.

It is time to politicize the Amazon, not militarize it. Conservation advocacies should focus on socio-economic empowerment of vulnerable populations. Military enforcement should be a rare last resort.

It is time to listen to the poorest 'illegal' people and let them shape policy. Creating new megareserves, even if appropriate, is rarely an effective solution. Combating deforestation requires helping workers to find livelihoods while participating equitably in the intricate politics of nature.

Samuel J. Spiegel Geography Department, University of Cambridge, Downing Place, Cambridge CB2 3EN, UK

\section{Deforestation: damage from dams adds to emissions}

SIR - In your Special Report

'Brazil goes to war against logging' (Nature 452, 134-135; 2008), you argue that the Brazilian government is willing to stop logging operations on the Amazon and to push down Brazil's greenhouse-gas emissions. But the Brazilian government still plans to build several hydroelectric power plants on the Amazon (see http://tinyurl. com/5hb6st), which could increase both deforestation and greenhouse-gas emissions.

Dams flood thousands of hectares of forest and threaten many aspects of the Amazon basin. Some are already being built in the Amazon headwaters and will interfere with the migratory route of economically and ecologically important fish. The previous construction of such barrages was a huge mistake, as sediment transportation to the lowlands (where soil is poor) was blocked and the excess of dead trees in the reservoir caused high water eutrophication.

Dams have also been implicated in methane and carbon dioxide emissions, in part because of organic-matter decomposition in the reservoirs. These emissions from artificial lakes should be considered along with Amazon logging and burning in calculations of Brazil's total greenhouse-gas emissions.

The Brazilian government needs to look at some proposed solutions, such as renewing non-productive 30-year-old dams (already built next to energy-consuming regions, but they would keep methane emissions at today's levels) or imposing a solar-energy policy that could reduce greenhousegas emissions if dams were decommissioned. Unfortunately, it does not look as though this will happen.

André Frainer Barbosa Post-Graduation Program on Ecology, Universidade Federal do Rio Grande do Sul, CEP: 91501-970, Porto Alegre, Brazil

\section{Hype around nanotubes creates unrealistic hopes}

SIR - In your News story 'Stemcell claim gets cold reception' (Nature 452, 132; 2008), you report on an announcement that nanotubes have been used to reprogramme adult human cells. As you say, the result was met with scepticism because it was proclaimed at an investors' meeting, rather than in a peerreviewed publication. There are also questions about the nanotechnological aspects of the work.
Carbon nanotubes are capable of penetrating cell membranes to facilitate cytoplasmic delivery, but their application in medicine is still in its infancy. Much more basic research is needed before deterministic assertions - such as those contained in the company announcement - can be made about the way carbon nanotubes act biologically and pharmacologically. Furthermore, no preclinical therapeutic efficacy data exist yet for any disease using a carbon nanotube construct.

The announcement was unclear about the exact nature of the studies carried out and the promised capabilities of both the carbon nanotubes and stem cells. For example, what was actually delivered by the carbon nanotubes? Proteins, DNA, small interfering RNA, or all three? Dramatically different delivery-system specifications are necessary for successful intracellular delivery and guaranteed biological activity for each of these, making the notion that 'carbon nanotubes deliver all' too simplistic.

The field of medical applications of carbon nanotubes and nanotechnology in general is particularly prone to hype. Claims that nanomaterials can contribute to new treatments of devastating diseases have led to confusion and misrepresentation, risking discreditation of this exciting area of research. We urge caution and patience, and call for sustained investment in basic research and systematic investigation by multidisciplinary teams, to keep expectations realistic.

Kostas Kostarelos Nanomedicine Laboratory, Centre for Drug Delivery Research, The School of Pharmacy, University of London, 29-39 Brunswick Square, London WC1N 1AX, UK Alberto Bianco CNRS, Institut de Biologie Moléculaire et Cellulaire, Laboratoire d'Immunologie et Chimie Thérapeutiques, 15 rue René Descartes, 67000 Strasbourg, France Maurizio Prato Dipartimento di Scienze Farmaceutiche, Università di Trieste, Piazzale Europa 1, 34127 Trieste, Italy 